\title{
Crossing the Final Frontier: Exploring the Numeracy Demands of Texts Read in English Language Arts
}

Ellen C. Agnello

University of Connecticut, ellen.cavanaugh@uconn.edu

Kevin M. Agnello

University of Connecticut, kevin.agnello@uconn.edu

Follow this and additional works at: https://digitalcommons.usf.edu/numeracy

Part of the Curriculum and Instruction Commons, Language and Literacy Education Commons, and the Secondary Education Commons

\section{Recommended Citation}

Agnello, Ellen C., and Kevin M. Agnello. "Crossing the Final Frontier: Exploring the Numeracy Demands of Texts Read in English Language Arts." Numeracy 12, Iss. 2 (2019): Article 7. DOI: https://doi.org/10.5038/ 1936-4660.12.2.7 


\title{
Crossing the Final Frontier: Exploring the Numeracy Demands of Texts Read in English Language Arts
}

\author{
Abstract \\ Incited by the National Assessment of Educational Progress' 2009 Reading Framework and the Common \\ Core State Standards, recent shifts in national education goals have urged English language arts teachers \\ to make curriculum adjustments. One such adjustment is to shift their focus from fiction, which has \\ traditionally dominated the curriculum, to nonfiction. Doing so has the potential to increase students' \\ exposure to informational texts which often employ numeric modes to represent quantitative data, thus \\ necessitating numeracy knowledge. This article presents a study of 60 nonfiction texts taught in \\ secondary ELA classrooms. Through analysis of these texts, it addresses the questions: Which nonfiction \\ texts are ELA teachers assigning to their students? and What are the numeracy demands of these texts? \\ Findings reveal not only the important role that mathematical representations play in the nonfiction texts \\ students read in their English language arts classes but also implications for English language arts \\ research and instruction.

\section{Keywords} \\ English language arts, numeracy, literacy, reading comprehension, nonfiction text, informational text, text \\ complexity

\section{Creative Commons License}

\section{c) (7) (8)} \\ This work is licensed under a Creative Commons Attribution-Noncommercial 4.0 License

\section{Cover Page Footnote} \\ Ellen Agnello is a doctoral student in reading education at the University of Connecticut. She holds an \\ M.Ed from Providence College and a B.A. in English from Connecticut College. She is certified by the state \\ of Connecticut to teach secondary English language arts and reading. Previously, she taught English \\ language arts for seven years, which inspired her to return to school to study literacy. She is interested in \\ the intersection of numeracy and literacy, especially the presence of mathematical representations in \\ nonfiction texts, and how these representations impact readability. \\ Kevin Agnello is a doctoral student in Measurement, Evaluation, and Assessment at the University of \\ Connecticut. He also holds an M.Ed in Education and a B.S. in Mathematics and Finance from the \\ University of Connecticut. He taught high school mathematics for two years, focusing specifically on \\ numeracy skill instruction.
}




\section{Introduction}

This study explores the need for numeracy instruction in English language arts (ELA) by examining the numeracy demands of nonfiction texts taught in secondary ELA classes. Though the skills that comprise literacy are commonly taught in ELA, those associated with numeracy are not, even though, depending on the text type, numeracy can enhance comprehension (Chapman \& Lee 1990). Evidence of this literacy-numeracy divide can be traced through educational reforms, many of which sought to fight it, highlighting the need for citizens to be both literate and numerate and urging schools to emphasize both skill sets.

Each year, in response to communication trends, English words are entered into the Oxford English Dictionary (OED), legitimizing their use and immortalizing them. According to the OED, to be selected for entry, words must be used over time in a range of contexts by various speakers (Oxford Dictionaries 2014). Recent entries to the OED include "retweet" and "hashtag," both of which were added in 2007, and "selfie," added in 2002. Surprisingly, terms that seem still in their infancy, such as "LOL" and "gif" earned their spots over 30 years ago, in the late 1980s, while "emoji" and "meme" joined in the late 1990s. The entry dates of words we assume to be English mainstays continue to surprise. Though not shocking that "literacy" was admitted in 1880, it seems odd that its not-too-distant relative, "numeracy," lagged behind by nearly 80 years, earning its spot in 1959, only 30 years prior to "LOL." Now that's laughable! Its entry corresponds to the publication of the Crowther Report (Crowther 1959), a document that details observed issues with English education and recommends specific reform efforts. One major focus of the report is the dual stress on literacy and numeracy. It proposes that a primary goal of higher educational institutions "should be to send out into the world men and women who are both literate and numerate" (Crowther 1959, 270) and further contends that numeracy, which it defines as an understanding of the scientific method and the ability to think quantitatively, "has come to be an indispensable tool [and therefore the educated] need to be numerate as well as literate" (Crowther 1959, 71).

The term "numeracy" quickly gained popularity among the educational discourse community in the years following the Crowther Report's publication. In 1982, Mathematics Counts (Great Britain \& Cockroft) was released, calling more specifically for mathematics education reform in England and Wales. It cited the Crowther Report's definition of numeracy, suggesting that resulting from colloquial use in the years succeeding its publication, its meaning mutated, coming to connote basic arithmetic skills. The Report urged for a return to increased rigor and technicality, defining numeracy as 
an at-homeness with numbers and an ability to make use of mathematical skills which enables an individual to cope with the practical mathematical demands of his everyday life ... an ability to have some appreciation and understanding of information which is presented in mathematical terms, for instance in graphs, charts or tables or by reference to percentage increase or decrease. (Great Britain and Cockroft 1982, 11)

Overall, the report calls for individuals to recognize and understand that, like words, mathematics can be used as a means of communication (Great Britain \& Cockroft 1982). An issue with this report, however, is that it was written specifically to an audience of mathematics educators, thereby implying that the teaching of numeracy skills is their responsibility alone.

The 1989 American publication Everybody Counts (National Research Council), echoes the calls for reform outlined in Mathematics Counts. It argues that to function in today's society, numeracy is as essential as verbal literacy (National Research Council 1989), implying that the new demands of our technologydependent world necessitate numeracy skills. Unlike Mathematics Counts, which positioned numeracy as within the purview of mathematics only, Everybody Counts acknowledged that numeracy is needed for all citizens to create a solid "foundation for lifelong work in the information age" (National Research Council 1989, 2), not just those pursuing careers in mathematics.

Since the publication of the Crowther Report, numeracy has been acknowledged by a wide range of disciplines and applied to a variety of contexts, further shaping its meaning. Still, a push for it to be associated with a broader skill set than basic arithmetic exists. The National Numeracy Network defines it as "the power and habit of mind to search out quantitative information, critique it, reflect upon it, and apply it in [our] public, personal and professional lives" and the Quantitative Literacy Design Team assembled by the National Council on Education and the Disciplines (2001) identified the following as among essential competencies of numeracy:

- Ability to interpret public data

- Application of quantitative information to decision making

- Confidence with mathematics

- Cultural appreciation of mathematics

- Logical thinking in forming opinions

- Practical problem-solving skills

- Strong number and symbol sense

- Use of mathematics in context

More recently, many have argued that these vital comprehensive skills be taught in all content areas, not just mathematics (Steen 2001; Thornton \& Hogan 2004; Bookman et al. 2008; Bennison 2015). Mimicking the OED entry trend, Bookman et al. (2008) declare that the time has come to embrace numeracy across the curriculum, pointing out that while mathematics and science educators once scoffed at the idea, reading and writing across the curriculum have become widely 
promoted and accepted initiatives. Bennison (2015) asserts that students who are taught numeracy skills across the curriculum are more empowered to apply them in a range of contexts than those who develop them solely through mathematics. Thornton \& Hogan (2004) back this argument, citing the literature on the transfer of learning. They similarly contend that students do not automatically exercise their mathematical knowledge in contexts other than mathematics. Therefore, if they are expected to use numeracy skills outside of the mathematics classroom, such as in the real world or their daily life experiences, as much of the literature recommends (Great Britain \& Cockroft 1982; Rivera-Batiz 1992; Hallett 2003; Steen 2004; Rothman et al. 2006; Wiest et al. 2007), they must be given the time and space to apply their skills in new settings, such as their content area classes (Thornton \& Hogan 2004).

\section{Theoretical Framework}

Though literacy and numeracy are often portrayed in opposition to each other, or as similar basic skill sets to be applied in different contexts (Chapman \& Lee 1990), this study employs the social semiotic theory of multimodality to suggest that literacy and numeracy skills must be applied in concert to make meaning from texts that contain multiple modes of representation: especially verbal and numeric. Multimodality acknowledges that texts incorporate diverse modes and symbol systems and that people must therefore use a variety of resources to make meaning in social situations (Bezemer et al. 2012). Analyzing the various modes and resources and how people utilize them to communicate with others sheds light on the central role that humans play in meaning making (Alvermann 2009). When considering how to represent a concept, an individual must decide which of its features is most salient. That feature becomes the mode through which the individual communicates the concept. At the same time, it indicates the speaker's disposition towards the concept and perception of the audience's interests and needs (Alvermann 2009).

This theory has major implications for the ELA discipline and nonfiction text comprehension. Steen (2001) suggests that as the printing press necessitated people's need for literacy, the computer-with its capacity to create, store, and share mass amounts of quantitative data - warranted the need for numeracy. The 21 st century technology boom incited the quantification of our world, elevating data as the most privileged mode of communication (Shreiner 2017). Quantitative data is now used to communicate all kinds of information, such as market trends, public opinion, and health-related phenomenon (Steen 1999). Because it has become the most salient and persuasive feature of information, texts that inform have become increasingly multimodal (Carney \& Levin 2002). In addition to text and pictures, the texts often display quantitative information through mathematical 
representations and data visualizations that require knowledge of various phenomena and sign complexes (Roth 2002) not often encountered in ELA classes that traditionally promote the reading of fiction. Readers of multimodal informational texts are expected to automatically and fluidly maneuver between sign complexes and weave their meanings together to achieve comprehension (Carney \& Levin 2002; Frith \& Prince 2009). What is unclear, however, is if students possess the requisite skills and knowledge to make meaning from these multimodal texts and if teachers are aware of the increased demands that these texts impose upon them (Frith \& Prince 2009). Before we can explore these uncertainties, we must first find out if the texts taught in ELA classes do, in fact, employ both verbal and mathematical representations to convey information.

\section{Literature Review Numeracy and Science}

Teaching numeracy across the curriculum might be easier than we think, as many content area curriculum materials already utilize mathematical representations which contain numeracy events, or "occasions in which a numeracy activity is integral to the nature of the participants' interactions and interpretive processes" (Street \& Baker 2006, 201) in addition to verbal text features. For instance, the quantitative dimension of science curriculum materials has been explored, though most research has focused on the graphical representations that appear alongside the text rather than the numeracy events, like the mathematical terms and statistics embedded in it. McTigue and Flowers (2011) focused specifically on students' diagrammatic literacy related to elementary and intermediate science textbooks. Many of the diagrams found in these instructional materials contain quantitative elements such as numbers and measurements. Echoing Chapman and Lee (1990), they concluded that students often assume these diagrams directly represent the text, or that they contain the same information as it. As a result, they invest their cognitive energy on the text, skipping over diagrams, which they assume do not require sustained attention.

Coleman et al. (2011) explored teachers' use of graphical representations in elementary teaching and found that 8 of 14 different types of graphical representations were most used in science teaching, though participants reported that the most frequently used strategy to instruct students' graphical comprehension was the teacher physically pointing to the graphical representation. Yeh and McTigue (2009) investigated the appearance of graphical representations, such as graphs, tables, and charts, in standardized science tests and discovered that more than half of all test items included graphical representations, the majority of which contained information essential to identifying the correct answers to test questions. The authors of these studies concluded that, in science classes, students are often 
presented with visual representations of quantitative data and therefore need more explicit instruction in graphical comprehension to develop their numeracy skills.

\section{Numeracy and Social Studies}

The numeracy demands of social studies curriculum materials have also been explored, but similar to the research conducted in the sphere of science, much of it attends to data visualizations that appear alongside text, again neglecting the embedded numeracy events. Shreiner (2016), for instance, examines the need for data literacy in $\mathrm{K}-12$ social studies classes, whereas in science, students are often presented with visual displays of quantitative information such as bar graphs, line graphs, pie charts, and tables. Nearly 3,000 data visualizations were found in the 38 social studies textbooks analyzed. To illustrate the frequency of their appearance, Shreiner (2016) explains that, on average, high school students encounter a new visualization every 4.8 pages, meaning they are required to exercise their numeracy skills frequently. In a similar study, Shreiner (2017) analyzes a new set of 42 social studies textbooks for the number, type, and function of data visualizations. This time, she finds that the majority of data visualizations provided information that elaborated upon the text, suggesting that they displayed information the text did not. This indicates that to achieve full comprehension of these texts, students must comprehend data visualizations in addition to text, which is often only possible by applying numeracy knowledge and mathematical thinking.

\section{Numeracy and Higher Education}

The numeracy demands of curriculum materials used at the college and university level have also been investigated. In response to the increasing volume and complexity of numeracy events in university curriculum materials, Frith and Prince (2009) created a framework for identifying and naming the demands they impose on students' numeracy competencies. They explain that almost all disciplinesincluding those, such as the humanities, which appear non-quantitative in natureplace numeracy demands on students, and they argue that because instructors are so fluent in all aspects of their disciplines, these demands often go unidentified. In a subsequent study, Frith and Gunston (2011) apply the framework to all printed curriculum materials made available to students enrolled in a first-year integrated human biology/epidemiology/ biochemistry course at the University of Cape Town. Resulting from this analysis, the authors conclude that curriculum materials assume students have strong numeracy skills, when in reality they may not (Frith \& Gunston 2011). Like Shreiner (2016) and Coleman et al. (2011), they also find that students are expected to interact with a variety of visual representations that display complex quantitative information. The authors encourage instructors to use their framework to make quantitative curriculum demands visible for themselves and their students. 
Also illustrating the momentum of the movement to embrace numeracy across the curriculum in higher education, Henes (2018) conducted a historical case study of a national professional development program entitled Mathematics Across the Curriculum (MAC3), established to support community college instructors' efforts to embed numeracy in their courses. The purpose of the case study was to explore how instructors applied their professional learning to unite in interdisciplinary collaborations and engage students in projects requiring the application of numeracy skills. In one such project, students completed a persuasive speech assignment that required them to identify a target audience, analyze its demographic composition using descriptive statistics, and articulate how demographics influence speech construction and delivery.

Kemp (2005) also explores the numeracy demands of non-mathematical courses by examining university students' reading and interpreting of data tables in an education course. After engaging in conversation with university staff, Kemp (2005) concludes that while students in non-mathematical subjects frequently encounter quantitative material, they are not typically instructed how to interpret it. In these classes, students are responsible for developing and applying these vital skills on their own (Kemp 2005). Research in higher education suggests that numeracy across the curriculum is possible and necessary, but not always done or done well.

\section{Numeracy and English Language Arts}

Though numeracy across the curriculum is gaining momentum, as evinced by the volume of literature on the numeracy dimensions of science, social studies, and higher education curricula, it has yet to breach the last frontier: ELA. What is often imagined to be the traditional ELA curriculum, composed of fictional classics, may seem about as far removed from mathematics as possible. However, recent shifts in national education goals have pushed ELA teachers to adjust their curricula, making their classrooms more hospitable to numeracy-rich texts. For instance, the Common Core State Standards (CCSS), released in 2009, propose that ELA teachers move their focus from fiction, which has traditionally dominated the curriculum, to nonfiction, so that by senior year, students would read nonfiction text across the curriculum 70\% of the time (National Governors Association Center for Best Practices, \& Council of Chief State School Officers 2010).

Though the document is persistent in its call for ELA teachers to teach nonfiction texts, CCSS never explicates what is meant by nonfiction. Instead, it uses three terms interchangeably: "literary nonfiction," "informational text," and "expository text." By using these terms at random, the CCSS leads ELA teachers to believe that these vastly different text types are the same in structure, features, and the cognitive demands they place on readers. However, fiction and nonfiction 
are umbrella terms that encompass multiple genres of text that can be structured by narration, exposition, or both (Maloch \& Bomer 2013).

For instance, nonfiction genres such as biography and memoir are often structured by narration. In some contexts, including NAEP's 2009 Reading Framework (National Center for Educational Statistics n.d.), because of their shared purpose, which is to provide readers with a literary experience, these genres are classified as "literary nonfiction" and grouped into the category of "literary text" along with fictional genres such as poetry and plays (National Center for Educational Statistics n.d.). On the other hand, many nonfiction genres, such as arguments, explanations, and informational writing, are primarily structured by exposition (Maloch \& Bomer 2013). NAEP's 2009 Reading Framework classifies these genres as "informational text" because their purpose is to inform readers (National Center for Educational Statistics n.d.). Unlike literary texts that often contain words only, informational texts employ multiple modes to represent information (Chapman \& Lee 1990). In addition to words, they utilize symbols, such as numbers and mathematical signs representing various operations, and visuals, including pictures, tables, charts, and graphs (Chapman \& Lee 1990). These modes of representation are included to increase the text's accessibility, but for readers who lack the specific competencies required to navigate them, like those composing numeracy, comprehension proves to be very difficult.

\section{The Problem}

The ambiguity of the CCSS forces the agency of nonfiction text selection on ELA teachers who often have little training in selecting, reading, and teaching informational text. This is because most ELA teachers studied English literature, which emphasizes literary texts. With little guidance from the standards, teachers may feel pressured to teach nonfiction texts but lack confidence in their ability (Stotsky 2012). Though studies have explored ELA teacher text selection (Jipson \& Paley 1991; Applebee 1993; Wollman-Bonilla 1998; Stallworth et al. 2006; Friese et al. 2008), few have examined nonfiction text selection exclusively. This means that not much is known about the nonfiction texts taught by ELA teachers, including the types, the characteristics that increase their complexity, and the cognitive demands they place on students. We know that informational texts differ from literary texts in many ways, including that they are often quantitative, containing mathematical ideas and representations which need to be read differently than verbal items (Chapman \& Lee 1990). Therefore, reading informational texts often requires mathematical thinking, which ELA teachers may not automatically consider encouraging their students to activate.

This oversight is problematic because when students read mathematical texts in non-mathematical contexts, they often read the mathematical representations 
non-mathematically or not at all, resulting in an incomplete and subsequently inadequate comprehension (Chapman \& Lee 1990). Since the release of the CCSS in 2009, ELA teachers have reported an increase in their emphasis of nonfiction texts (Loveless 2015), but how do they define nonfiction and how frequently do they teach informational texts? In the context of reading informational text, literacy often depends on numeracy. Therefore it would seem that if informational texts are frequently taught in ELA classrooms, ELA teachers should embrace the numeracy across the curriculum initiative and explicitly teach numeracy in the context of informational text. The purpose of this study was to explore the nonfiction texts ELA teachers assign to see if they contain numeracy demands thus necessitating explicit numeracy instruction within the ELA classroom. This study was guided by the following research questions: (1) which nonfiction texts are ELA teachers assigning to their students, and (2) what are the numeracy demands of these texts?

\section{Method Sample and Data Collection}

In the winter of 2018, emails were sent to Connecticut high school ELA department heads and curriculum coordinators asking them to invite their teachers to participate in this study. In-person meetings were scheduled with teachers who agreed to participate. All meetings took place at the teachers' schools. During meetings, teachers were asked to provide copies of the nonfiction texts they felt best represented those students read in their classrooms. If copies were unavailable, teachers listed source information, including titles and authors. These meetings produced a total of 41 texts. Nonfiction text was intentionally not defined in these meetings. This omission allowed teachers to provide any text they felt qualified, which created a more accurate representation of the participating teachers' interpretations of the term.

Often, during meetings, teachers were more inclined to list the online sources they use to locate nonfiction texts instead of providing the texts themselves. They explained that unlike their fiction curricula, the nonfiction texts, which often depict current events, are ever-changing. Some teachers also said that they allow students to visit certain websites and select articles independently. In all, the teachers cited ten different online platforms that they use for nonfiction text selection (Appendix A), but every participant indicated frequent use of Newsela, which is an online collection of curated nonfiction texts grouped by content area and theme. It appeals to teachers for a number of reasons, one being its compatibility with differentiation. Once a Newsela editor selects an article from Forbes, The New York Times, or another widely-read news outlet, it is sent to a writer for simplification. The writer produces up to five iterations of the text at varying levels of complexity or Lexile. The website boasts that this allows teachers to assign the same text to readers at 
different skill levels. Because so many teachers indicated use of the articles hosted on Newsela.com, an additional 35 texts from four of its Literature Text Sets section were selected (Appendix A). The four text sets included "Harrison Bergeron" by Kurt Vonnegut, "Thank You Ma'am" by Langston Hughes, Black Boy by Richard Wright, and Of Mice and Men by John Steinbeck. Newsela's Literature Text Sets prescribe nonfiction articles for teachers to assign while teaching the classic works of fiction that typically populate ELA curricula. The nonfiction articles provide information related to the conflicts and themes presented in commonly taught novels and short stories. Adding the articles from the four Newsela Literature Text Sets to those collected from the participating ELA teachers, yielded 76 texts in total.

\section{Data Analysis}

Text Type. Like Moss (2008) who analyzed text types in basal readers and Watkins \& Liang (2014) who analyzed text types in literature anthologies used in the middle grades, the texts collected in this study were classified according to the text types delineated and defined in the 2009 NAEP Reading Framework (National Center for Educational Statistics n.d.). This framework groups texts into two main categories: literary and informational. Therefore, these categories were used when classifying the texts collected from the ELA teacher participants and Newsela. Literary texts, which include fiction, poetry, plays, and literary nonfiction, often use story grammar and are structured by narrative (Mandler \& Johnson 1977; Thorndyke 1977; Stein et al. 1979), whereas informational texts, which include expository, argumentative and persuasive text, procedural text, and documents, do not (Watkins \& Liang 2014).

Numeracy Events. A manifest content analysis (Potter \& Levine-Donnerstein 1999) of 60 of the 76 texts was conducted to determine the quantity of numeracy events, or "occasions in which a numeracy activity is integral to the nature of the participants' interactions and their interpretive processes" (Street \& Baker 2006). To assist in the identification of numeracy events, a set of criteria based on Street \& Baker's definition was created (2006). In order to qualify as a numeracy event, an item could consist of any mode of representation, including words, mathematical symbols, visuals (graphs or tables), or any combination thereof (O'Halloran 2005). The item must also require readers to apply numeracy skills and/or knowledge to make inferences and these inferences must be essential to comprehension. Ultimately, an item qualified as a numeracy event if it contained quantitative information from which a reader could construct meaning through inference. The texts were coded by two researchers, both of whom were secondary teachers and are currently educational researchers. The primary researcher taught ELA and the secondary researcher taught mathematics, focusing specifically on numeracy. The primary and secondary researcher coded $25 \%$ of the texts, or 15 texts. The percent 
agreement was $87 \%$, meaning the two raters agreed on the count of numeracy events in 13 of the 15 texts. The two coders deliberated when disagreements occurred, each providing a rationale, and then came to consensus. The primary researcher proceeded to code the remaining 45 texts.

Identification of Numeracy Events. Figure 1 depicts an excerpt of the data collected in this study. By applying the aforementioned criteria, three numeracy events were identified. The first is "About 20\%." To interpret this numeracy event, the reader would initially have to identify the percent sign and understand that it implies a proportion. Neglecting or misinterpreting this symbol would result in the inability to construct meaning from it and, more importantly, from this part of the text. Upon successful identification and interpretation of the percent sign, the reader must then apply mathematical thinking to recognize that combined with the number "20" it implies the proportion 20/100. By relating the verbal context, the reader can infer that this proportion means one in five of the 11 to 18 -year-olds who participated in the survey, which can further be interpreted as less than half, or one quarter, of the participants. Finally, it is left to the reader to infer the gravity of that number in the context described.

About $20 \%$ of nearly 4,400 11-18 year-olds surveyed by the Cyberbullying Research Center in 2010 reported having been cyberbullied at some point in their lives.

Figure 1. An excerpt of an article collected from an ELA teacher participant entitled "Should States and the Federal Government Pass Further Anti-Bullying Legislation to Target Cyberbullying?" (Facts on File 2010).

The second numeracy event is "more than 4,400." To make meaning from this, the reader must recognize that the combination of the words "more than" and the number " 4,400 " implies 4,401 or any number greater. If the first numeracy event were successfully interpreted, meaning that the reader was able to activate knowledge of proportions to conclude that "about 20\%" is about one-fifth, the reader could also transfer that understanding to this construct, dividing 4,400 by 5 to arrive at about 880 participants. Again, it is left to the reader to determine if the number 880 adolescents out of 4,400 surveyed is substantial.

The third numeracy event is "11-18." To understand this representation the reader would have to decide, based on what has already been read and by applying numeracy knowledge, if the dash between the numbers implies a range of ages or requires the reader to perform subtraction. If the reader correctly infers an age range, then he or she can infer that respondents are $11,12,13,14,15,16,17$, and 18 years-old. If the reader is unable to apply mathematical thinking to interpret 
these numeracy events and instead chooses to skip them, this sentence loses its meaning completely. Though they seem fleeting and minor, these three numeracy events are essential to comprehending this passage and understanding the text.

\section{Results}

\section{Which Nonfiction Texts Are ELA Teachers Assigning?}

The bibliographic information of the 41 texts collected from the ELA teacher participants is outlined in Appendix B. Of the 41 texts, 25 (or 61\%) were informational and 16 (or 39\%) were literary. Interestingly, though the majority of the literary texts were literary nonfiction, some were not. These included works of historical fiction, like The Things They Carried by Tim O'Brien, and realistic fiction, like Sold by Patricia McCormick and Nineteen Minutes by Jodi Picoult. Table 1 displays the number and percentage of text types collected from ELA teacher participants.

Table 1

Texts Collected from ELA Teacher Participants

\begin{tabular}{|c|c|}
\hline Text Type & Number (Percentage) \\
\hline Informational & $25(61 \%)$ \\
\hline Literary & $16(39 \%)$ \\
\hline Literary Nonfiction & $12(75 \%)$ \\
\hline Memoir & 8 \\
\hline Biography & 3 \\
\hline Essay & 1 \\
\hline Fiction & $4(25 \%)$ \\
\hline Historical & (2) \\
\hline Realistic & 2 \\
\hline Total & $41(100 \%)$ \\
\hline
\end{tabular}

Table 2

Texts Collected from Newsela.com

\begin{tabular}{|c|c|}
\hline Text Type & Number (Percentage) \\
\hline Informational & $28(80 \%)$ \\
\hline Literary & $7(20 \%)$ \\
\hline Literary Nonfiction & $7(100 \%)$ \\
\hline Biography & (200 \\
\hline Speech & 1 \\
\hline Total & $35(100 \%)$ \\
\hline
\end{tabular}


Of the 35 articles selected from the Newsela Literature Text Sets, 28 (or 80\%) were informational, and 7 (or 20\%) were literary. Unlike those collected from the ELA teacher participants, all of the literary texts collected from Newsela were literary nonfiction. Table 2 displays the number and percentage of text types collected from Newsela for analysis.

\section{What Are the Numeracy Demands of These Texts?}

Table 3 outlines the number and frequency of numeracy events identified in the articles collected from teacher participants and Newsela. Although 41 texts were collected from the ELA teacher participants, only the 25 informational texts were analyzed as it was initially hypothesized that the literary nonfiction texts would contain an insubstantial number of numeracy events. To test this hypothesis, all texts collected from Newsela, including literary nonfiction texts, were analyzed.

Table 3

Number and Frequency of Numeracy Events in Texts Collected from ELA Teacher Participants and Newsela.com

\begin{tabular}{llll}
\hline \hline & Number of Texts & $\begin{array}{l}\text { Number of Numeracy } \\
\text { Events }\end{array}$ & $\begin{array}{l}\text { Average Number of } \\
\text { Numeracy Events Per } \\
\text { Article }\end{array}$ \\
\hline ELA Teacher Participants & 25 & 310 & 12.40 \\
Newsela.com & $28(7)^{*}$ & $429(31)^{*}$ & $15.32(4.43)^{*}$ \\
\hline \hline
\end{tabular}

*Informational texts (Literary texts)

Sample of Text Collected from ELA Teacher Participants. In total, 310 numeracy events were identified in the 25 informational texts collected from the ELA teacher participants, which is an average of 12.4 numeracy events per article. However, the average number of numeracy events per article varied by ELA teacher participant. For instance, the articles collected from one teacher contained five numeracy events, on average, whereas the articles collected from another teacher, who teaches the same subject at the same school, contained 19 numeracy events on average. Additionally, the number of numeracy events varied greatly within the sample of articles collected from each teacher. For instance, of the 6 articles collected from one teacher, one entitled "Stop Blaming Every Social Ill on Helicopter Parents-Binge Drinking Included" (Stevens 2016) did not contain any numeracy events, while another entitled "Should States and the Federal Government Pass Further Anti-Bullying Legislation to Target Cyberbullying?" (Facts on File 2010), contained 37.

Sample of Text Collected from Newsela.com. A similar pattern emerged during the analysis of the 28 informational articles sampled from Newsela. A total of 429 
numeracy events, or just over 15 per article, were identified, though the average number of numeracy events per article varied by text set. For instance, the six informational articles that compose the "Harrison Bergeron" text set contained 29 numeracy events, or about five per article, while the eight informational articles that compose the Black Boy text set contained 227 numeracy events, or about 28 per article.

Like the articles collected from the ELA teacher participants, the number of numeracy events varied greatly within the text sets. One of the 11 texts in the Black Boy set, entitled "How Do People Create Knowledge?" (Bain 2016) contained 4 numeracy events, whereas another, entitled "World's 85 Richest Have Wealth Equal to Half the World Population" (Schofield 2014), contained 74 numeracy events. Surprisingly, most of the literary nonfiction texts included in the four text sets also contained numeracy events. In fact, the three literary nonfiction texts from the Black Boy text set contained 15 numeracy events in total, or about 5 per article, which is a slightly higher ratio than the 29 numeracy events identified in the six informational texts that comprise the "Harrison Bergeron" text set, or about 4.8 per article. This unexpected finding was not the norm. Overall, the seven literary nonfiction texts found in the four text sets analyzed had 31 numeracy events, or 4.4 per article.

\section{Discussion}

Mathematical representations, which contain numeracy events, make up one of the many modes of communication that have become increasingly common in our technology-infused, quantified society (Steen 2001). These representations of quantitative information have not only pervaded our televisions, newspapers, computers, and smartphones, but they have inundated our schools across the curriculum and are no longer confined to mathematics and science classrooms. This study aimed to determine what types of nonfiction texts ELA teachers are assigning and whether those texts necessitate explicit numeracy instruction within the context of the ELA classroom.

The findings reveal that mathematical representations containing numeracy events play a prominent role in the nonfiction texts read in the ELA classroom. Most of these texts are informational and, on average, they contain more than 10 unique numeracy events, requiring readers to identify implicit signals of mathematical thinking, which can be comprised of words, numbers, symbols, and visuals. Upon identifying these signals, readers must activate and apply the appropriate mathematical thinking to make meaning. Successful readers of these texts must therefore possess both knowledge of a range of quantitative representations including fractions and ratios, percentages, basic arithmetic, inequalities, and correlations, as well as knowledge of the various words, symbols, 
and visuals that are commonly used to communicate them. This requires several of the essential competencies of numeracy outlined by the Quantitative Literacy Design Team (National Council on Education and the Disciplines 2001), including confidence with mathematics, strong number and symbol sense, the use of mathematics in context, and practical problem-solving skills.

The presence of numeracy events in texts read in ELA classrooms indicates that numeracy across the curriculum is possible and necessary. It evinces that ELA teachers, in addition to math, science, and social studies teachers, should assume the responsibility of numeracy teaching. When reading nonfiction texts in ELA, students can practice identifying numeracy events, activating their mathematical knowledge, and applying it to make inferences just as they would with instances of foreshadowing when learning about suspense or irony. Assimilating this ability is essential for students to participate more fully in their lives, communities, and society as application of numeracy skills to text is needed to make sense of global issues like climate change (Kahan et al. 2012), food labels (Rothman et al. 2006), medical and risk communications (Gakumo et al. 2013), and newspaper articles (Maier 2003). Explicitly teaching numeracy skills through nonfiction text in ELA can help prepare our students for the quantitative demands of our society.

Doing so does not come without challenges. Perhaps resulting from the incongruence between the definitions of text types provided by the NAEP framework and the CCSS, there seems to be a wide range of interpretations of the term nonfiction text. As evinced by this study, teachers primarily understand nonfiction to denote informational and literary nonfiction text, as $61 \%$ of texts collected from participants were informational and $29 \%$ were literary nonfiction. Some teachers, however, are confusing works of historical and realistic fiction for nonfiction text. ELA teachers who primarily understand nonfiction to mean literary text might not see the value in teaching numeracy skills in the ELA classroom, as texts that fall into this category tend to have substantially fewer numeracy events and therefore place fewer demands on students' numeracy competencies. This was seen in the analysis of Newsela articles in which literary nonfiction articles contained 4.42 numeracy events on average while informational texts contained 15.32 numeracy events on average. Those who primarily teach informational text might not be conscious of the cognitive demands that numeracy events impress upon readers, even if they are highly numerate and competent readers of informational text themselves (Frith \& Prince 2009).

Additionally, the data analyzed in this study suggests that numeracy events can be comprised of multiple modes of representation. While we might automatically look for numbers and symbols representing mathematical operations when trying to locate numeracy events in text, we must also attend to visuals, like timelines, graphs, and tables, and words that signify mathematical ideas like "majority," "decrease," "more than," "rate," "growth," "doubled," "decline," and "drew even" 
to name a few. It is easy to forget that terms like these activate mathematical thinking because they appear so frequently in the texts we read daily (Raymond \& Schield 2008).

In all conversations with participating teachers, it was revealed that websites like Newsela appeal because they offer high quality nonfiction text that aligns to existing ELA curricula at varying readability levels. This makes it easy for ELA teachers, who may lack experience in nonfiction text selection, analysis, and teaching to one-stop shop instead of spending countless hours searching the vast expanse of the World Wide Web for a text that is both relevant and accessible. Though the data analyzed in this study shows that articles hosted on Newsela contain more numeracy events, on average, than those selected by ELA teachers from other sources, it is important to note that only texts at the highest Lexile were analyzed and therefore the frequency of numeracy events present in Newsela's simplified article iterations is unknown.

Unfortunately, students who lack the numeracy competencies needed to draw inferences from numeracy events in informational texts are likely to miss important information. Carney and Levin (2002) assert that now more than ever, written prose is accompanied by illustration, and the same appears to be true about mathematical representations and numeracy events. Levin (1981) proposes that illustrations serve five distinct purposes in text, the most common of which is representation (Fingeret 2012). A graphic is representational when it provides the same information as the written prose. While attending to representational graphics can support, enhance, or reinforce text comprehension, it is not essential to meaning making. After analyzing thousands of graphics in hundreds of texts used in second and third grade science and social studies, Fingeret (2012) found these categories to be lacking and added a sixth: extension. Extensional graphics introduce information that the written prose does not, making these graphics vital to text comprehension. Like illustrations, the data procured through this study suggests that numeracy events can similarly be used represent or reiterate.

An example of a representational numeracy event was found in one of the Newsela articles collected from the Black Boy text set, entitled "Why People Try Repulsive Things" (May 2016). The text reads, "Despite the increased risk for negative consequences, participants clicked significantly more pens in the uncertain-outcome condition (51 percent) than in the certain-outcome condition (30 percent)" (May 2016). The author initially used the words "significantly more ... than" (May 2016), to connote a comparison which is itself a numeracy event. By adding the secondary numeracy events, "(51 percent)" and "(30 percent)," the author reinforces for numerate readers that participants in the uncertain-outcome condition clicked more pens than those in the certain-outcome condition. In this example, making inferences from the secondary numeracy events could improve or 
reinforce comprehension but is not essential to it as long as readers can identify the comparison introduced by the first numeracy event.

On the other hand, also like graphics, mathematical representations can extend the text, conveying information that has not yet been shared in non-mathematical terms. The Newsela article "In Some States, Low Poverty Rate Obscures Deeper Despair" (Grovum 2014) contains 48 numeracy events, almost all of which are extensional. One sentence reads, "But 36 percent of Massachusetts' low-income residents are living in deep poverty, which is 10th highest among the states and D.C." (Grovum 2014). In order to comprehend this sentence, readers would need to apply their mathematical knowledge to interpret the two numeracy events, "36 percent" and "10th highest," because the meaning they contain cannot be made from the text otherwise. Unlike graphics, which contain information that can almost always be conveyed through verbal text, numeracy events are used in informational text to render quantitative information, which cannot be expressed nonmathematically. Therefore, one might suggest that numeracy knowledge is paramount in the context of comprehending text that communicates quantitative information.

This study also revealed that students' exposure to numeracy-rich texts in their ELA classes is variable. The data indicates that even those who are in the same grade at the same school may be exposed to different proportions of numeracy events in the texts they are assigned to read. This finding is evinced by the texts collected from two participants who teach the same grade at the same school. One provided five texts containing 97 numeracy events in total, or nearly 20 per article, while the other provided six texts with 31 numeracy events, or about five per article. This could suggest that the first teacher values numeracy more than the second or that both teachers are unaware of the numeracy demands present in the texts they assign, and the differences occurred at random. Further research is needed to better understand why gaps, such as this, exist.

\section{Conclusion}

The aim is that this study will serve as a starting point for future research on the nonfiction texts taught in ELA classrooms and the demands that these texts place on students' numeracies. The data suggest that as long as ELA students are required to read informational text, there is a need for explicit numeracy instruction. However, a larger sample size may make generalizability of this finding more feasible. Additionally, this study did not explore the frequency with which ELA students are asked to read nonfiction texts, whether they be informational, literary, or both. Therefore, its findings cannot be used to recommend that ELA teachers devote a prescribed number of curriculum hours to numeracy instruction. 
A natural next step for this work would be to investigate how often students are asked to read the different nonfiction text types in their ELA classes as well as teacher motivations for nonfiction text selection. Such an exploration may illuminate the characteristics and features that ELA teachers attend to and neglect during nonfiction text selection, clarifying their level of perception of the mathematical representations and numeracy demands present. Additionally, this study begs an exploration of text simplification software, like Newsela, to see what happens to numeracy events when the text is simplified. This might reveal how students' reading levels impact their exposure to numeracy rich texts. Two questions that emerged in this study should be further investigated. The first is: Which modes are most commonly used to represent numeracy events in nonfiction text? The second is: How do numeracy events function in nonfiction text? Uncovering the answers to these questions might assist ELA teachers in identifying the numeracy demands of the nonfiction texts their students read and understanding how these demands impact meaning making.

The final and possibly most important next step would be to study ELA students' numeracy skills in the context of reading nonfiction text as well as their attention to the numeracy events present in the texts they read. This would enable us to see if ELA students neglect numeracy events, assuming they contain information the written prose has already expressed, as was found with science students and graphical representations (McTigue \& Flowers 2011). There is clearly a lot of work to be done to better understand how great the need for numeracy instruction is in the context of ELA and there is even more work to be done to identify possible strategies ELA teachers can use to build students' numeracy skills for improved comprehension of nonfiction text. This work seems limitless, because we are just now crossing the final frontier of the numeracy across the curriculum initiative, but hopefully doing so will soon benefit ELA teachers and their students.

\section{References}

Alvermann, Donna E. 2009. "Sociocultural Constructions of Adolescence and Young People's Literacies." Handbook of Adolescent Literacy Research: 1428.

Applebee, Arthur N. 1993. Literature in the Secondary School: Studies of Curriculum and Instruction in the United States. Urbana, IL: National Council of Teachers of English.

Bain, Bob. 2016. "How Do People Create Knowledge?" Edited by Newsela Staff. Retrieved from https://newsela.com/read/BHP-U2-0-approachesknowledge/id/3637/quiz/0/ 
Bennison, Anne. 2015. "Supporting Teachers to Embed Numeracy Across the Curriculum: A Sociocultural Approach.” ZDM 47, no. 4: 561-573. https://doi.org/10.1007/s11858-015-0706-3

Bezemer, Jeff, Sophia Diamantopoulou, Carey Jewitt, Gunther Kress, and Diane Mavers. 2012. Using a Social Semiotic Approach to Multimodality: Researching Learning in Schools, Museums and Hospitals. Working paper no. 01/12. March. Accessed January 12, 2019. http://eprints.ncrm.ac.uk/2258/4/NCRM_working_paper_0112.pdf.

Bookman, Jack, Susan L. Ganter, and Rick Morgan. 2008. "Developing Assessment Methodologies for Quantitative Literacy: A Formative Study." The American Mathematical Monthly 115, no. 10: 911-929. https://doi.org/10.1080/00029890.2008.11920609

Carney, Russell N., and Joel R. Levin. 2002. "Pictorial Illustrations Still Improve Students' Learning from Text." Educational Psychology Review 14, no. 1: 526. https://doi.org/10.1023/A:1013176309260

Chapman, Anne and Alison Lee. 1990. "Rethinking Literacy and Numeracy." Australian Journal of Education 34, no. 3: 277-289.

Coleman, Julianne M., Erin M. McTigue, and Laura B. Smolkin. 2011. 'Elementary Teachers' Use of Graphical Representations in Science Teaching." Journal of Science Teacher Education 22, no. 7: 613-643. https://doi.org/10.1007/s10972-010-9204-1

Crowther, Geoffrey. 1959. "A Report of the Central Advisory Council for Education." Fourth Report 15-18.

Facts on File. 2010. "Should States and the Federal Government Pass Further Anti-Bullying Legislation to Target Cyberbullying?" Facts on File Issues and Controversies. December 6. Retrieved from https://www.infobase.com/product/schools/issues-controversies-online-2/.

Fingeret, Lauren. 2012. "Graphics in Children's Informational Texts: A Content Analysis.” PhD diss., Michigan State University. https://eric.ed.gov/?id=ED546078

Friese, Elizabeth E., Donna E. Alvermann, Adam Parkes, and Achariya T. Rezak. 2008. "Selecting Texts for English Language Arts Classrooms: When Assessment Is Not Enough." English Teaching: Practice and Critique 7, no. 3: 74-99.

Frith, Vera, and Geney Gunston. 2011. "Towards Understanding the Quantitative Literacy Demands of a First-year Medical Curriculum." African Journal of Health Professions Education 3, no. 1: 19-23.

Frith, Vera, and Robert Prince. 2009. "A Framework for Understanding the Quantitative Literacy Demands of Higher Education.” South African Journal of Higher Education 23, no. 1: 83-97. https://doi.org/10.4314/sajhe.v23i1.44804 
Gakumo, C. Ann, David E. Vance, Linda D. Moneyham, Joy P. Deupree, and Carlos A. Estrada. 2013. "Health Numeracy and Health Literacy Within the Context of Management of Patients with Human Immunodeficiency Virus." Nursing: Research and Reviews 3: 23-31. https://doi.org/10.2147/NRR.S37548

Great Britain, and W.H. Cockroft. 1982. Mathematics Counts: Report of the Committee of Inquiry into the Teaching of Mathematics in Schools under Chairmanship of W.H. Cockroft. London: H.M.S.O.

Grovum, Jake. 2014. "In Some States, Low Poverty Rate Obscures Deeper Despair." Edited by Newsela Staff. Retrieved from https://newsela.com/read/poverty-incomegap/id/5375/quiz/0/

Henes, Matthew. 2018. "Quantitative Literacy Across the Community College Curriculum: A Qualitative Case Study of Mathematics Across the Community College Curriculum (MAC3)." PhD diss., UCLA. https://escholarship.org/uc/item/8tg04341

Hallett, Deborah Hughes. 2003. "The Role of Mathematics Courses in the Development of Quantitative Literacy." In Quantitative Literacy: Why Numeracy Matters for Schools and Colleges, edited by Bernard L. Madison and Lynn A. Steen, 91-98. Princeton, NJ: The National Council on Education and the Disciplines.

Jipson, Janice, and Nicholas Paley. 1991. "The Selective Tradition in Teachers' Choice of Children's Literature: Does It Exist in the Elementary Classroom?" English Education 23, no. 3: 148-159.

Kahan, Dan M., Ellen Peters, Maggie Wittlin, Paul Slovic, Lisa Larrimore Ouellette, Donald Braman, and Gregory Mandel. 2012. "The Polarizing Impact of Science Literacy and Numeracy on Perceived Climate Change Risks." Nature Climate Change 2, no. 10: 732-735. https://doi.org/10.1038/nclimate1547

Kemp, Marian. 2005. "Developing Critical Numeracy at the Tertiary Level." PhD diss., Murdoch University.

Levin, Joel R. 1981. "On Functions of Pictures in Prose.” In Neuropsychological and Cognitive Processes in Reading, edited by Francis J. Pirozzolo and Merlin C. Wittrock, 203-226. New York, NY: Academic Press. https://doi.org/10.1016/B978-0-12-185030-2.50013-5

Loveless, Tom. 2015. "Has Common Core Influenced Instruction?" Brown Center Chalkboard. https://www.brookings.edu/blog/brown-centerchalkboard/2015/11/24/has-common-core-influenced-instruction/

Maier, Scott R. 2003. "Numeracy in the Newsroom: A Case Study of Mathematical Competence and Confidence." Journalism \& Mass Communication Quarterly 80, no. 4: 921-936. https://doi.org/10.1177/107769900308000411 
Maloch, Beth, and Randy Bomer. 2013. "Informational Texts and the Common Core Standards: What Are We Talking About, Anyway?" Language Arts 90, no. 3: 205-213.

Mandler, Jean M., and Nancy S. Johnson. 1977. "Remembrance of Things Parsed: Story Structure and Recall." Cognitive Psychology 9, no. 1: 111-151. https://doi.org/10.1016/0010-0285(77)90006-8

May, C. 2016. "Why People Try Repulsive Things." Edited by Newsela Staff. Retrieved from https://newsela.com/read/why-people-eat-disgustingthings/id/18478/

McTigue, Erin M., and Amanda C. Flowers. 2011. "Science Visual Literacy: Learners' Perceptions and Knowledge of Diagrams." The Reading Teacher 64, no. 8: 578-589. https://doi.org/10.1598/RT.64.8.3

Moss, Barbara. 2008. "The Information Text Gap: The Mismatch Between Nonnarrative Text Types in Basal Readers and 2009 NAEP Recommended Guidelines." Journal of Literacy Research 40, no. 2: 201-219. https://doi.org/10.1080/10862960802411927

National Center for Educational Statistics. "What Does the NAEP Reading Assessment Measure?" National Assessment of Educational Progress, accessed January 1, 2019.

https://nces.ed.gov/nationsreportcard/reading/whatmeasure.aspx\#sec5.

National Council on Education and the Disciplines, Mathematics and Democracy: The Case for Quantitative Literacy, The Woodrow Wilson National Fellowship Foundation, Princeton, NJ, 2001.

National Governors Association Center for Best Practices, \& Council of Chief State School Officers. 2010. "English Language Arts Standards: Introductions: Key Design Considerations" Common Core State Standards Initiative, accessed December 21, 2018. Retrieved from http://www.corestandards.org/ELA-Literacy/introduction/key-designconsideration/.

National Numeracy Network. “About This Journal.” Numeracy, accessed January 1, 2019. https://scholarcommons.usf.edu/numeracy/about.html.

National Research Council. 1989. Everybody Counts: A Report to the Nation on the Future of Mathematics Education. Washington, DC: National Academy Press.

O’Halloran, Kay. 2005. Mathematical Discourse: Language, Symbolism and Visual Images. London: Continuum.

Oxford Dictionaries. 2014. "How Do New Words Get Added to Oxford Dictionaries?" Oxford Dictionaries video, August 14, https://blog.oxforddictionaries.com/2014/08/14/how-do-new-words-getadded-oxford-dictionaries/. 
Potter, W. James, and Deborah Levine-Donnerstein. 1999. "Rethinking Validity and Reliability in Content Analysis." Journal of Applied Communication Research 27: 258-284. https://doi.org/10.1080/00909889909365539

Raymond, Robert, and Milo Schield. 2008. "Numbers in the News: A Survey." In Proceedings of the ASA Section on Statistical Education.

Rivera-Batiz, Francisco L. 1992. "Quantitative Literacy and the Likelihood of Employment Among Young Adults in the United States." Journal of Human Resources: 313-328. https://doi.org/10.2307/145737

Roth, Wolff-Michael. 2002. "Reading Graphs: Contributions to an Integrative Concept of Literacy." Journal of Curriculum Studies 34, no. 1: 1-24. https://doi.org/10.1080/00220270110068885

Rothman, Russell L., Ryan Housam, Hilary Weiss, Dianne Davis, Rebecca Gregory, Tebeb Gebretsadik, Ayumi Shintani, and Tom A. Elasy. 2006. "Patient Understanding of Food Labels: The Role of Literacy and Numeracy." American Journal of Preventive Medicine 31, no. 5: 391-398. https://doi.org/10.1016/j.amepre.2006.07.025

Schofield, Matthew. 2014. "World's 85 Richest Have Wealth Equal to Half the World Population." Edited by Newsela Staff. Retrieved from https://newsela.com/read/richest-85/id/2495/.

Shreiner, Tamara L. 2016. "Increasing Students' Access to Information: A Case for Increased Attention to Data."

Shreiner, Tamara L. 2017. "Data Literacy for Social Studies: Examining the Role of Data Visualizations in K-12 Textbooks." Theory \& Research in Social Education 46, no. 2: 194-231. https://doi.org/10.1080/00933104.2017.1400483

Stallworth, B. Joyce, Louel Gibbons, and Leigh Fauber. 2006. "It's Not on the List: An Exploration of Teachers' Perspectives on Using Multicultural Literature." Journal of Adolescent \& Adult Literacy 49, no. 6: 478-489. https://doi.org/10.1598/JAAL.49.6.3

Steen, Lynn A. 1999. "Numeracy: The New Literacy for a Data-drenched Society," Educational Leadership 57, no. 2: 8-13.

Steen, Lynn A. ed. 2001. Mathematics and Democracy: The Case for Quantitative Literacy. Princeton, NJ: The National Council on Education and the Disciplines.

Steen, Lynn Arthur. 2004. Achieving Quantitative Literacy: An Urgent Challenge for Higher Education. USA: Mathematics Association of America.

Stein, Nancy L., Christine G. Glenn, and Roy Freedle. 1979. "An Analysis of Story Comprehension in Elementary School Children." New Directions in Discourse Processing 2: 1-68.

Stevens, Heidi. 2016. "Stop Blaming Every Social Ill on Helicopter ParentsBinge Drinking Included.” Retrieved from 
https://www.chicagotribune.com/lifestyles/stevens/ct-helicopter-parentingbinge-drinking-balancing-0804-20160804-column.html

Stotsky, Sandra. 2012. "Issue Brief: Common Core Standards' Devastating Impact on Literary Study and Analytical Thinking." Heritage Foundation, no. 3800: 1-2.

Street, Brian, and Dave Baker. 2006. "So, What About Multimodal Numeracies." Travel Notes from the New Literacy Studies: 219-233. https://doi.org/10.21832/9781853598630-012

Thorndyke, Perry W. 1977. "Cognitive Structures in Comprehension and Memory of Narrative Discourse.” Cognitive Psychology 9, no. 1: 77-110. https://doi.org/10.1016/0010-0285(77)90005-6

Thornton, Steve, and John Hogan. 2004. 'Orientations to Numeracy: Teacher's Confidence and Disposition to Use Mathematics across the Curriculum." International Group for the Psychology of Mathematics Education 4: 313320.

Watkins, Naomi M., and Lauren Aimonette Liang. 2014. "The 'Literature' of Literature Anthologies: An Examination of Text Types." Middle Grades Research Journal 9, no. 2: 57-73.

Wiest, Lynda R., Heidi J. Higgins, and Janet Hart Frost. 2007. "Quantitative Literacy for Social Justice.” Equity \& Excellence in Education 40, no. 1: 4755. https://doi.org/10.1080/10665680601079894

Wollman-Bonilla, Julie E. 1998. “Outrageous Viewpoints: Teachers' Criteria for Rejecting Works of Children's Literature.” Language Arts 75, no. 4: 287295.

Yeh, Yi-Fen Y., and Erin M. McTigue. 2009. "The Frequency, Variation, and Function of Graphical Representations Within Standardized State Science Tests." School Science and Mathematics 109, no. 8: 435-449. https://doi.org/10.1111/j.1949-8594.2009.tb18291.x 


\section{Appendices}

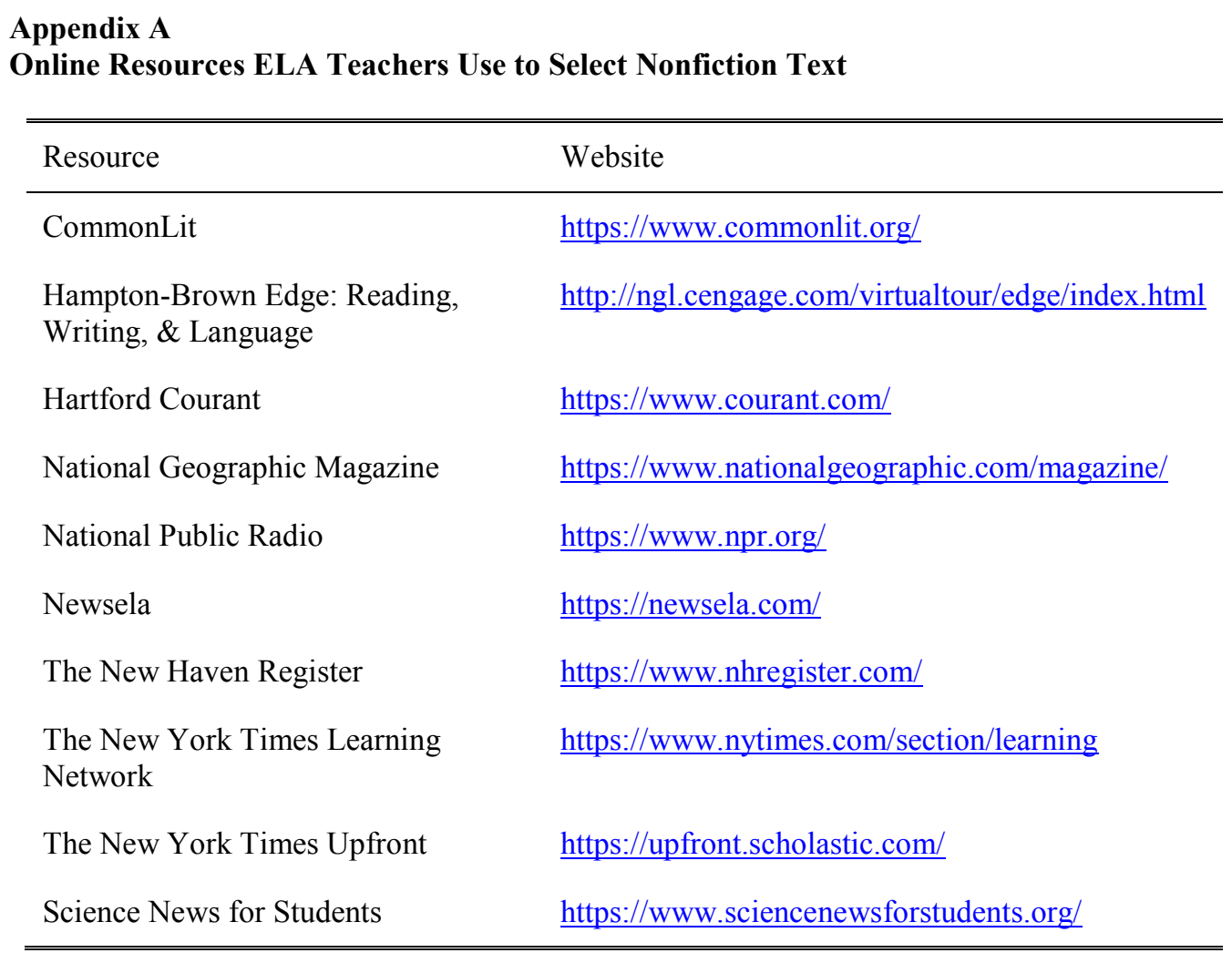




\section{Appendix B}

Bibliographic Information of Texts Collected from ELA Teacher Participants and Newsela

\begin{tabular}{|c|c|}
\hline Texts Collected from ELA Teacher Participants & Text Type \\
\hline A humorous protector* & Informational \\
\hline $\begin{array}{l}\text { Alvarez, J. 2010. In the Time of the Butterflies. Chapel Hill, NC: } \\
\text { Algonquin Books of Chapel Hill. }\end{array}$ & $\begin{array}{l}\text { Fiction; } \\
\text { Historical }\end{array}$ \\
\hline $\begin{array}{l}\text { Angelou, M. 2010. I Know Why the Caged Bird Sings. New York, } \\
\text { NY: Random House. }\end{array}$ & $\begin{array}{l}\text { Literary } \\
\text { Nonfiction: } \\
\text { Memoir }\end{array}$ \\
\hline $\begin{array}{l}\text { Beah, I. 2007. A Long Walk to Water: Memoirs of a Boy Soldier. } \\
\text { New York, NY: Sarah Crichton Books. }\end{array}$ & $\begin{array}{l}\text { Literary } \\
\text { Nonfiction: } \\
\text { Memoir }\end{array}$ \\
\hline $\begin{array}{l}\text { Bissinger, H. G. 2000. Friday Night Lights. Boston, MA: Addison- } \\
\text { Wesley. }\end{array}$ & $\begin{array}{l}\text { Literary } \\
\text { Nonfiction }\end{array}$ \\
\hline $\begin{array}{l}\text { Brooks, D. 2005. Mind over muscle. Retrieved from } \\
\text { https://www.nytimes.com/2005/10/16/opinion/mind-over- } \\
\text { muscle.html }\end{array}$ & Informational \\
\hline $\begin{array}{l}\text { Celebrity Gossip: Is It Harmless Entertainment? 2014. Facts on File } \\
\text { Issues and Controversies. April 28. Retrieved from } \\
\text { https://www.infobase.com/product/schools/issues-controversies- } \\
\text { online-2/. }\end{array}$ & Informational \\
\hline $\begin{array}{l}\text { Darnton, K. 2017. "What Happens When Parents Loosen Up a Bit? } \\
\text { Look to the Dutch." Retrieved from } \\
\text { https://www.bostonglobe.com/magazine/2017/06/06/what-happens- } \\
\text { when-parents-loosen-bit-look- } \\
\text { dutch/mVmOHsADKLXwOFF2Y0ISCJ/story.html }\end{array}$ & Informational \\
\hline $\begin{array}{l}\text { Davis, S., Jenkins, G., \& Hunt, R. 2006. We Beat the Streets: How a } \\
\text { Friendship Pact Led to Success. New York, NY: Puffin Books. }\end{array}$ & $\begin{array}{l}\text { Literary } \\
\text { Nonfiction: } \\
\text { Memoir }\end{array}$ \\
\hline $\begin{array}{l}\text { Dumas, F. 2007. Funny in Farsi: A Memoir of Growing up Iranian } \\
\text { in America. New York, NY: Random House. }\end{array}$ & $\begin{array}{l}\text { Literary } \\
\text { Nonfiction; } \\
\text { Memoir }\end{array}$ \\
\hline Federman, E. 2013. "Bullying Is Bad, but Criminalizing Bullying & Informational \\
\hline
\end{tabular}

Could Be Even Worse." Retrieved from

https://www.forbes.com/sites/realspin/2013/10/23/bullying-is-bad-

but-criminalizing-bullying-would-be-even-worse/\#5bc107581446 
Griffin, D. 2015. Free Range Parenting: Easier Said than Done but Worth the Effort." Retrieved from https://www.psychologytoday.com/us/blog/thoughtful-parenting-indistracted-times/201507/free-range-parenting

Hillenbrand, L. 2010. Unbroken: A World War II Story of Survival, Resilience, and Redemption. New York, NY: Random House.

"Is Extreme Parenting Effective?" 2011. Facts on File Issues and Controversies. March 28. Retrieved from https:/www.infobase.com/product/schools/issues-controversiesonline-2/.

Jones, L. Y. 2014. "Too Many Celebrities, Not Enough Heroes." Retrieved from https://www.washingtonpost.com/opinions/toomany-celebrities-not-enough-heroes/2014/02/28/dbfc3f5c-98e0$11 \mathrm{e} 3-80 \mathrm{ac}-$

63a8ba7f7942_story.html?noredirect $=$ on\&utm_term $=.38609046$ eee 5

Krakauer, J. 2009. Into the Wild. New York, NY: Anchor Books.

Lewis, J., Ayden, A., \& Powell, N. 2013. March: Book One. Marietta, GA: Top Shelf Productions.

"Malala Yousafzai: A Normal yet Powerful Girl.” 2013. CommonLit. Retrieved from https://www.commonlit.org/en/texts/malala-yousafzai-a-normal-yetpowerful-girl.

McCormick, P. 2006. Sold. New York, NY: Hyperion Books for Children.

Nordland, R. 2017. “Afghanistan's Romeo and Juliet.” Retrieved from https://upfront.scholastic.com/issues/201718/090417/afghanistan-s-romeo-and-juliet.html

O'Brien, T. 1990. The Things They Carried. New York, NY: Houghton Mifflin.

Phan, N., \& Syed, S. 2014. "Teens Aren't Fairly Portrayed in Media." Retrieved from

https://princetonsummerjournal.com/2014/08/11/teens-arent-fairlyportrayed-in-media/
Informational

Literary

Nonfiction;

Biography

Informational

Informational

\author{
Literary \\ Nonfiction; \\ Biography \\ Literary \\ Nonfiction; \\ Memoir/Graphic \\ Novel \\ Informational
}

Fiction;

Realistic

Informational

Fiction;

Historical

Informational 
Picoult, J. 2008. Nineteen Minutes. New York, NY: Washington Square Press.

Shapiro, A. 2012. "American Dream Faces Harsh New Reality." Retrieved from https://www.commonlit.org/en/texts/americandream-faces-harsh-new-reality.

"Should School Be a Place for Debate?" 2015. Strategic Education Research Partnership's Word Generation. Retrieved from http://www.cal.org/create/conferences/2012/pdfs/handout-2-snowhurley.pdf.

"Should States and the Federal Government Pass Further AntiBullying Legislation to Target Cyberbullying?" 2010. Facts on File Issues and Controversies. December 6. Retrieved from https://www.infobase.com/product/schools/issues-controversiesonline- $2 /$.

"Should States Pass Laws Requiring Educational Institutions to Implement Anti-Bullying Measures?" 2014. Facts on File Issues and Controversies. October 31. Retrieved from https://www.infobase.com/product/schools/issues-controversiesonline-2/.

Smith, P. 2014. “Too Young to Say 'I do'?” Retrieved from https://upfront.scholastic.com/issues/2016-17/042417/too-young-tosay-i-do-.html.

Smith, P. 2017. "Wheels of Progress." Retrieved from https://upfront.scholastic.com/issues/2017-18/103017/wheels-ofprogress.html

Stevens, H. 2016. Stop Blaming Every Social Ill on Helicopter Parents-Binge Drinking Included." Retrieved from https://www.chicagotribune.com/lifestyles/stevens/ct-helicopterparenting-binge-drinking-balancing-0804-20160804-column.html

"Superstitions: Humans Fear What They Cannot Control or Understand." 2017. Newsela. October 12. Retrieved from https://newsela.com/read/elem-the-fear-of-13/id/35642.

"The Factory Fire"*

"The Mothman Legend"*

Toppo, G. 2012. "Should Bullies Be Treated as Criminals?" Retrieved from http://usatoday30.usatoday.com/news/nation/story/2012-0612/bullying-crime-schools-suicide/55554112/1.
Fiction;

Realistic

Informational

Informational

Informational

Informational

Informational

Informational

Informational

Informational

Informational

Informational

Informational 
Walker, R. 2004. "Putting Down the Gun." In R. Walker (Ed.), What Makes a Man: 22 Writers Imagine the Future (pp. 1-7). New York, NY: Riverhead Books.

Walls, J. 2005. The Glass Castle. New York, NY: Scribner.

"Wandering for the Love of God"*

Wiesel, E. 2013. Night. New York, NY: Hill and Wang.

Wilson, G. W. 2010. The Butterfly Mosque: A Young Woman's Journey to Love and Islam. London, UK: Atlantic Books.

Zissou, R. 2017. "The Real Cost of Your Phone.” Retrieved from https://upfront.scholastic.com/issues/2017-18/103017/the-real-costof-your-phone.html.
Literary

Nonfiction:

Essay

Literary

Nonfiction:

Memoir

Informational

Literary

Nonfiction:

Memoir

Literary

Nonfiction:

Memoir

Informational

* Source information was not provided and could not be located for these texts.

Texts Collected from Newsela

Alder, D. 2016. "The Three Great Thinkers Who Changed

Economics." Edited by Newsela Staff. Retrieved from

https://newsela.com/read/BHP-U9-5-smith-marx-keynes/id/3958/

Amario, C., \& Christie, B. 2015. "States Consider Requiring US Citizenship Test for Graduation." Edited by Newsela Staff. Retrieved from https://newsela.com/read/civics-test/id/7034/

Bain, B. 2016. "How Do People Create Knowledge?" Edited by Newsela Staff. Retrieved from https://newsela.com/read/BHP-U2-0approaches-knowledge/id/3637/quiz/0/

Bauer, L. 2014. "Police Group Delivers after Seeing More 'Starving' Kids." Edited by Newsela Staff. Retrieved from https://newsela.com/read/starving-kids/id/6466/

Biography.com editors. 2016. "World's Leaders: Adolf Hitler." Edited by Newsela Staff. Retrieved from https://newsela.com/read/bio-worldleader-adolf-hitler/id/19527/

Biography.com editors. 2014. "World's Leaders: Joseph Stalin." Edited by Newsela Staff. Retrieved from https://newsela.com/read/bioworld-leader-joseph-stalin/id/19230/
Text Type

Informational

Informational

Informational

Informational

Literary Nonfiction: Biography

Literary

Nonfiction:

Biography 
Biography.com editors. 2016. "World's Leaders: Mao Zedong." Edited by Newsela Staff. Retrieved from https://newsela.com/read/bio-worldleader-mao-zedong/id/19538/

Brown, E. 2013. "Many Low-income Moms Struggling to Keep Babies in Clean Diapers." Edited by Newsela Staff. Retrieved from https://newsela.com/read/diapers-demand/id/725/

Brown, E. 2015. "This Superintendent Has Figured Out How to Make School Work for Poor Kids.” Edited by Newsela Staff. Retrieved from https://newsela.com/read/superintendent-poorschools/id/13795/

Dearon, J. 2016. "Ready, Set, Think! Mind Controlled Drones Race to the Future." Edited by Newsela Staff. Retrieved from https://newsela.com/read/braincontrolled-drone/id/17007/

"Famous Speeches: Margaret Chase Smith's Declaration of Conscience." 2016. Newsela. Retrieved from https://newsela.com/read/speeches-chasesmithdeclarationconscience/id/16509

Goldstein, D. 2015. "Why It's Hard to Be a Poor Boy with Richer Neighbors." Edited by Newsela Staff. Retrieved from https://newsela.com/read/poor-boy-rich-neighbors/id/18237/

Grovum, J. 2014. "How Asian Americans Are Changing the South." Edited by Newsela Staff. Retrieved from https://newsela.com/read/AsianAmericans-south/id/5549/

Grovum, J. 2014. "In Some States, Low Poverty Rate Obscures Deeper Despair." Edited by Newsela Staff. Retrieved from https://newsela.com/read/poverty-incomegap/id/5375/quiz/0/

Healy, M. 2016. "Deep Sleep Put the 'REM' in Remembering." Edited by Newsela Staff. Retrieved from https://newsela.com/read/deepsleepmemory/id/17669/

Hirsch, J. 2014. "In a Self-Driving Future, We May Not Even Want to Own Cars." Edited by Newsela Staff. Retrieved from https://newsela.com/read/selfdriving-future/id/6128/

Hussein, B., \& Mroue, B. 2016. "Report: Half of Syrian Refugee Children in Lebanon Not in School." Edited by Newsela Staff. Retrieved from https://newsela.com/read/refugees-school-syrialebanon/id/19872/

Jowit, J. 2016. “'Hidden Crisis' of Small Children Left Alone while Parents Work." Edited by Newsela Staff. Retrieved from https://newsela.com/read/children-homealone/id/15599/
Literary

Nonfiction:

Biography

Informational

Informational

Informational

Literary

Nonfiction:

Speech

Informational

Informational

Informational

Informational

Informational

Informational

Informational 
Knickmeyer, E. 2014. 'In Drought, 'Pop Up' Wetlands Provide Bird Habitat." Edited by Newsela Staff. Retrieved from https://newsela.com/read/popup-wetland/id/5218/

Kwon, D. 2015. "Poverty Disturbs Children's Brain Development, Academic Performance.” Edited by Newsela Staff. Retrieved from https://newsela.com/read/poverty-braindevelopment/id/11670/

Library of Congress and National Park Service. 2017. "Authors: Langston Hughes." Edited by Newsela Staff. Retrieved from https://newsela.com/read/bio-authors-langston-hughes/id/27275/

May, C. 2016. "Why People Try Repulsive Things.” Edited by Newsela Staff. Retrieved from https://newsela.com/read/why-peopleeat-disgusting-things/id/18478/

Makinen, J. 2015. "Japanese Fisherman in Post-tsunami Town Sees Hope in 'Dream oysters." 'Edited by Newsela Staff. Retrieved from https://newsela.com/read/japanese-oysters/id/7948/

Munro, D. 2015. "Photographer Honored by Time a Documentarian of Farmworkers." Edited by Newsela Staff. Retrieved from https://newsela.com/read/farm-photographer/id/7866/

Nichols, F. H. 2016. “Time Machine (1902): Children Working in Pennsylvania Coal Mines. Edited by Newsela Staff. Retrieved from https://newsela.com/read/historic-news-child-labor-coalmines/id/20173/

Ortiz, E. 2013. "Dry Farming Draws Interest from Small Growers." Edited by Newsela Staff. Retrieved from https://newsela.com/read/waterless-farming/id/239/

Pearce, M. 2015. “Church Fires Stir Fears, Questions.” Edited by Newsela Staff. Retrieved from https://newsela.com/read/churchfires/id/11024/.

Peoples, S., \& McCombs, B. 2016. "Romney Says Future 'Greatly Diminished' with Trump." Edited by Newsela Staff. Retrieved from https://newsela.com/read/romney-trumpattack/id/15452/

Pugliese, N. 2015. “For Parents, Sacrifices Worth It for Children's Athletic Careers." Edited by Newsela Staff. Retrieved from https://newsela.com/read/parents-sports/id/6802/

Rosenblum, G. 2014. "Ex-con Saved by Reading Uses Literacy to Combat Crime by At-risk Youth.” Edited by Newsela Staff. Retrieved from https://newsela.com/read/prison-literacy/id/5677/

Roth, M. 2014. "For 60 Years, America Officially Excluded Chinese
Informational

Informational

Literary

Nonfiction:

Biography

Informational

Informational

Literary

Nonfiction:

Biography

Informational

Informational

Informational

Informational

Informational

Literary

Nonfiction:

Biography

Informational 
People.” Edited by Newsela Staff. Retrieved from

https://newsela.com/read/chinese-exclusion/id/6189/

Schofield, M. 2014. "World's 85 Richest Have Wealth Equal to Half

Informational the World Population." Edited by Newsela Staff. Retrieved from https://newsela.com/read/richest-85/id/2495/.

Singer, P. 2016. “Opinion: Can Artificial Intelligence Be Ethical?"

Informational

Edited by Newsela Staff. Retrieved from https://newsela.com/read/aiethical/id/16920/

Susman, T. 2014. "At Memory Competition, the Diverse Contestants

Informational Are Unforgettable." Edited by Newsela Staff. Retrieved from https://newsela.com/read/memory-competition/id/4158/

UShistory.org. 2017. “The Harlem Renaissance.” Edited by Newsela

Informational Staff. Retrieved from https://newsela.com/read/lib-ushistory-harlemrenaissance/id/27284/ 